\title{
Unlikely role of glycolytic enzyme $\alpha$-enolase in cancer metastasis and its potential as a prognostic biomarker
}

\author{
Lachlan Schofield ${ }^{1,2}$, Lisa F. Lincz ${ }^{1,2,3}$, Kathryn A. Skelding ${ }^{1,2}$ \\ ${ }^{1}$ Faculty of Health and Medicine, Priority Research Centre for Cancer Research, Innovation and Translation, School of Biomedical \\ Sciences and Pharmacy, University of Newcastle, Callaghan, New South Wales 2308, Australia. \\ ${ }^{2}$ Hunter Cancer Research Alliance and Cancer Research Program, Hunter Medical Research Institute, New Lambton Heights, \\ New South Wales 2305, Australia. \\ ${ }^{3}$ Hunter Haematology Research Group, Calvary Mater Newcastle Hospital, Waratah, New South Wales 2298, Australia.
}

Correspondence to: Dr. Kathryn Skelding, School of Biomedical Sciences and Pharmacy, University of Newcastle, University Drive, Callaghan, New South Wales 2308, Australia. E-mail: kathryn.skelding@newcastle.edu.au

How to cite this article: Schofield L, Lincz LF, Skelding KA. Unlikely role of glycolytic enzyme $\alpha$-enolase in cancer metastasis and its potential as a prognostic biomarker. J Cancer Metastasis Treat 2020;6:10. http://dx.doi.org/10.20517/2394-4722.2019.43

Received: 5 Dec 2019 First Decision: 4 Mar 2020 Revised: 5 Mar 2020 Accepted: 24 Mar 2020 Published: 17 Apr 2020

Science Editor: Stephen J. Ralph Copy Editor: Jing-Wen Zhang Production Editor: Jing Yu

\begin{abstract}
Reliance on glycolysis for energy production is considered a hallmark of cancer and the glycolytic enzyme $\alpha$-enolase is overexpressed in a range of cancer types. However, recent studies have revealed that $\alpha$-enolase is involved in a variety of unrelated physiological processes and can be found in multiple unexpected cellular locations. This review focuses on the unlikely role of $\alpha$-enolase as an extracellular plasminogen-binding receptor localised to the plasma membrane. Conversion of plasminogen to plasmin on the surface of cancer cells enhances their ability to invade through stroma by activating collagenases and degrading fibrin as well as extracellular matrix proteins. Increased expression of $\alpha$-enolase is associated with increased migration and invasion of cancer cells, and decreased metastasis-free survival in patients with several cancer types, including non-small cell lung, pancreatic, breast and colorectal cancers. Due to its overexpression in a range of cancer types and multi-functional roles in key areas of tumour metabolism and metastasis, $\alpha$-enolase may be useful as a universal cancer prognostic biomarker or therapeutic target.
\end{abstract}

Keywords: Alpha-enolase, ENO1, metastasis, migration, invasion, proliferation, plasminogen-binding receptor

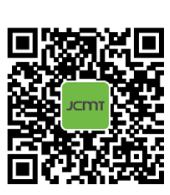




\section{INTRODUCTION}

All cancer cells have a high energy demand due to their increased rate of proliferation ${ }^{[1]}$. Increased glycolysis is considered a hallmark of cancer $^{[2]}$ and investigating glycolytic enzymes may yield new therapeutic approaches for cancer treatment. Enolases are key glycolytic enzymes ${ }^{[3]}$, and increased expression of one isoform, $\alpha$-enolase, has been identified in several cancer types ${ }^{[4-22]}$. This review provides an overview of the expression of $\alpha$-enolase and key functions it controls in cancer cells, with a focus on the potential role of $\alpha$-enolase as a cancer prognostic biomarker or therapeutic target.

\section{ENOLASE IS A GLYCOLYTIC ENZYME THAT HAS THREE ISOFORMS}

Enolases (EC 4.2.1.11) are metalloenzymes that catalyse the dehydration of 2-phospho-D-glycerate to phosphoenolpyruvate in the glycolysis pathway [Figure 1], and catalyse the hydration of phosphoenolpyruvate to 2-phopho- $D$-glycerate in the reverse anabolic pathway during gluconeogenesis ${ }^{[3]}$. In mammals, the three genes $E N O 1, E N O 2, E N O 3$ encode three isoforms, with expression being regulated in a tissue-specific manner. Alpha-enolase (ENO1) is ubiquitously expressed, whereas $\gamma$-enolase (ENO2) is primarily expressed in neurons and neuroendocrine tissues, and $\beta$-enolase (ENO3) in muscle tissues ${ }^{[23]}$. Active enolase consists of a dimer in which two subunits face each other in an antiparallel formation ${ }^{[24]}$, and requires two non-covalently bound magnesium ions as cofactors for enzyme activity ${ }^{[25]}$.

\section{ALPHA-ENOLASE IS A MULTI-FUNCTIONAL PROTEIN}

Although many glycolytic enzymes are considered to be housekeeping proteins, $\alpha$-enolase expression can vary dramatically depending on the stress, metabolic, or pathological state of the cell. A retrospective proteomic meta-analysis identified that $\alpha$-enolase was the most differentially expressed protein in humans and rodents irrespective of tissue type and pathological condition ${ }^{[26]}$. Disrupted expression and/or activity of $\alpha$-enolase has been reported in several pathologies with distinct aetiologies, including Alzheimer's disease, systemic sclerosis, rheumatoid arthritis, bacterial infections and hepatic fibrosis ${ }^{[27-38]}$.

Apart from its role in the glycolytic pathway, recent studies have revealed that $\alpha$-enolase is a multifunctional protein that controls a variety of cellular processes, including proliferation, survival, migration and invasion. Additionally, using an alternative transcription start codon, the ENO1 gene can produce a $37 \mathrm{kDa}$ protein, c-myc promoter-binding protein (MBP-1). MBP-1 localises to the nucleus, where it acts as a transcription repressor by binding to the $\mathrm{c}$-myc $\mathrm{P} 2$ promoter ${ }^{[39]}$, helping regulate and maintain the function of the glycolysis pathway.

\section{ALPHA-ENOLASE EXPRESSION IS ALTERED IN TUMOURS AND VARIES WITH CANCER TYPE}

The overexpression of $\alpha$-enolase is associated with tumour development via a process known as aerobic glycolysis or the Warburg effect. The Warburg effect has been hypothesised to be an adaptation mechanism in cancer cells to support the biosynthetic requirements of rapid proliferation. Alpha-enolase expression has been shown to be altered at the mRNA and/or protein level in a range of tumours [Table 1], and generally upregulated in most, including acute myeloid leukaemia (AML), glioma, melanoma, lymphoma, and colorectal, endometrial, gastric, head and neck, liver, ovarian and pancreatic cancer ${ }^{[4-22]}$.

\section{ALPHA-ENOLASE CAN SHUTTLE BETWEEN CELLULAR COMPARTMENTS}

Alpha-enolase can be localised to the cytoplasm and plasma membrane, as well as secreted in exosomes, and its location varies with cancer type. For example, in pancreatic, breast and lung tumours, $\alpha$-enolase is localised to the plasma membrane $e^{[22,44,45]}$, whereas in melanoma, mesothelioma, non-small cell lung, colorectal and prostate cancer $\alpha$-enolase is also secreted and found in exosomes ${ }^{[43,46-49]}$. Alpha-enolase can 


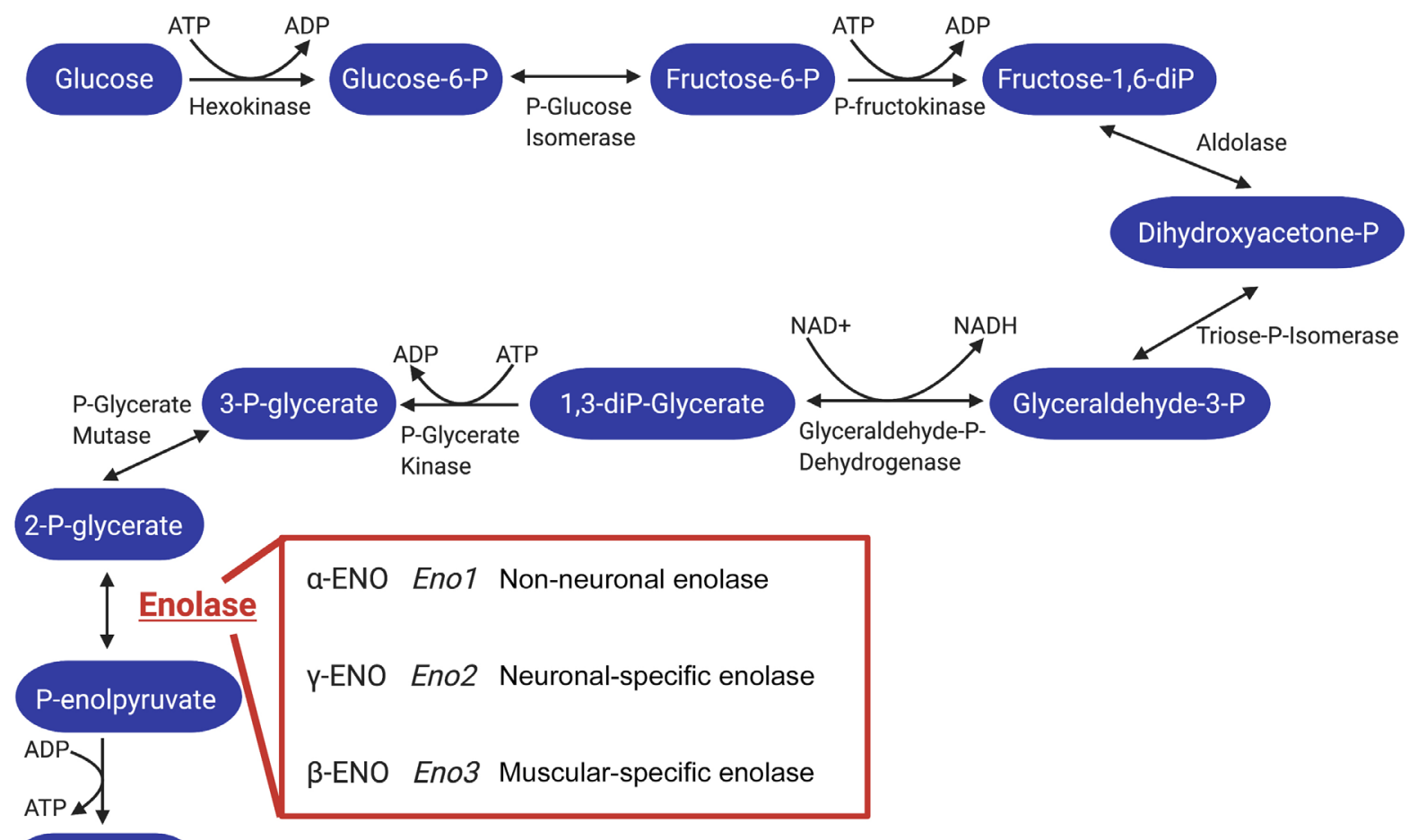

Pyruvate

Figure 1. The glycolysis pathway. Enolases catalyse the dehydration of 2-phospho-D-glycerate (2-P-glycerate) to phosphoenolpyruvate (P-enolpyruvate) in the glycolysis pathway

shuttle between compartments, performing different functions when in different subcellular locations, such as surface membrane plasminogen binding, controlling the overall metabolic state of the cell, stressrelated or acting as a heat-shock protein, RNA transport, mitochondrial membrane stability, and cell cycle control $^{[50-55]}$.

\section{INCREASED ALPHA-ENOLASE EXPRESSION ENHANCES CELL PROLIFERATION IN A VARIETY OF CANCERS}

In most solid tumours, the Warburg effect causes an increase in total glycolysis under both hypoxic and normoxic conditions [Figure 2]. Enhanced cell proliferation leads to increased anabolic needs, and cancer cells remodel metabolic processes by diverting nutrients to anabolic pathways to satisfy increased cellular energy demands ${ }^{[56]}$. Therefore, the Warburg effect may provide cancer cells with an advantage when competing with non-cancerous tissues for nutrients. This suggests that increased $\alpha$-enolase expression will contribute to enhanced proliferation commonly observed in cancer cells.

Indeed, upregulated $\alpha$-enolase expression has been shown to regulate cell proliferation in various solid tumours in vitro ${ }^{[1,13,57-61]}$, and to increase tumour growth in a HCT116 colorectal cancer xenograft model in vivo ${ }^{[11]}$ [Table 2]. Conversely, silencing of $\alpha$-enolase in glioma, pancreatic, lung, endometrial, colorectal and breast cancer cells was found to induce cell cycle arrest and senescence, and also to reduce tumour volume in CFPAC-1 pancreatic, MDA-MB-231 breast and U-87MG glioma xenograft models in vivo ${ }^{[6,11,12,62,63]}$. Furthermore, $\alpha$-enolase is also implicated in the control of apoptosis and sensitivity to chemotherapeutic agents, as silencing of ENO1 in cancer cells induced apoptosis and increased sensitivity to cisplatin and 5-fluorouracil in vitro ${ }^{[13,62,64]}$. Unexpectedly, cells respond to $\alpha$-enolase silencing by inducing catabolic adaptations that lead to restoration of pyruvate, acetyl-CoA bulk and oxidative phosphorylation, 
Table 1. The expression of $\alpha$-enolase is altered in cancer

\begin{tabular}{|c|c|c|c|c|}
\hline Cancer & Sample type & Detection method & $\begin{array}{l}\text { Alteration (frequency of } \\
\text { alteration) }\end{array}$ & Ref. \\
\hline AML & $\begin{array}{l}\text { Peripheral blood and bone marrow from AML } \\
\text { patients }(n=41) \text { and healthy patients }(n=20)\end{array}$ & Microarray & Increased & {$[4]$} \\
\hline \multirow[t]{2}{*}{ Breast cancer } & $\begin{array}{l}\text { Breast cancer tissue with adjacent matched } \\
\text { normal tissue }(n=24)\end{array}$ & Western blot & Increased (100\%) & [9] \\
\hline & Breast cancer and normal tissue $(n=244)$ & Quantitative real-time PCR & Decreased & {$[10]$} \\
\hline $\begin{array}{l}\text { Cervical } \\
\text { cancer }\end{array}$ & $\begin{array}{l}\text { Squamous cell carcinoma }(n=33) \text { and normal } \\
\text { cervical tissue }(n=17)\end{array}$ & $\begin{array}{l}\text { 2D-DIGE and MALDI-TOF } \\
\text { mass spectrometry }\end{array}$ & Increased & {$[40]$} \\
\hline \multirow[t]{2}{*}{$\begin{array}{l}\text { Colorectal } \\
\text { cancer }\end{array}$} & $\begin{array}{l}\text { SW620 cell line (lymph node metastasis) } \\
\text { compared to SW } 480 \text { (primary lesion) }\end{array}$ & 2D-DIGE & Increased & [41] \\
\hline & $\begin{array}{l}\text { Colorectal cancer }(n=48) \text { and adjacent matched } \\
\text { normal tissue }(n=16)\end{array}$ & $\mathrm{IHC}$ and $\mathrm{PCR}$ & Increased (56\%) & {$[11]$} \\
\hline $\begin{array}{l}\text { Endometrial } \\
\text { carcinoma }\end{array}$ & $\begin{array}{l}\text { Endometrial cancer }(n=100) \text {, endometrial } \\
\text { atypical hyperplasia }(n=22) \text { and normal } \\
\text { endometrium tissues }(n=20)\end{array}$ & $\mathrm{IHC}$ & $\begin{array}{l}\text { Increased in endometrial cancer } \\
(52 \%) \text { and atypical hyperplasia } \\
(31.8 \%) \text { compared to normal }\end{array}$ & {$[12]$} \\
\hline \multirow[t]{2}{*}{$\begin{array}{l}\text { Gastric } \\
\text { cancer }\end{array}$} & $\begin{array}{l}\text { Gastric cancer and adjacent normal tissue }(n= \\
94)\end{array}$ & $\mathrm{IHC}$ & Increased & [13] \\
\hline & Primary gastric cancer tissue $(n=107)$ & $\mathrm{IHC}$ & Increased (48\%) & [14] \\
\hline \multirow[t]{2}{*}{ Glioma } & Primary glioblastoma tissue $(n=24)$ & Quantitative real-time PCR & Increased (68\%) & {$[5]$} \\
\hline & Glioma $(n=136)$ and normal brain $(n=15)$ tissue & $\begin{array}{l}\text { Quantitative real-time PCR } \\
\text { and IHC }\end{array}$ & Increased (69\%) & {$[6]$} \\
\hline $\begin{array}{l}\text { Head and } \\
\text { neck cancer }\end{array}$ & $\begin{array}{l}\text { Head and neck cancer and adjacent normal } \\
\text { tissue }(n=44)\end{array}$ & Real-time PCR & Increased (50\%) & [15] \\
\hline $\mathrm{HCC}$ & $\begin{array}{l}\text { HCC }(n=374 \text { and } n=1309) \text {, adjacent matched } \\
\text { tissue }(n=50) \text {, and normal tissue }(n=1442) \\
\text { from TCGA and GEO data source; tissue } \\
\text { microarray ( } 93 \text { HCC and } 87 \text { normal liver tissues) }\end{array}$ & Microarray and IHC & Increased & [16] \\
\hline Lymphoma & $\begin{array}{l}\text { Pretherapeutic tumour biopsies from peripheral } \\
\text { T-cell lymphoma not otherwise classified }(n= \\
\text { 87) }\end{array}$ & $\mathrm{IHC}$ & Increased & {$[8]$} \\
\hline Melanoma & $\begin{array}{l}\text { A375, MeWo, MEL-HO, Colo- } 800 \text {, Colo- } 853 \\
\text { melanoma cell lines and a normal melanocyte } \\
\text { cell line }\end{array}$ & $\begin{array}{l}\text { 2D-DIGE and nano- } \\
\text { HPLC-chip ion trap mass } \\
\text { spectrometry }\end{array}$ & Increased & {$[7]$} \\
\hline \multirow[t]{3}{*}{ NSLC } & $\begin{array}{l}\text { Primary NSCLC tissue and matched normal lung } \\
(n=26) \text { from RNA and primary NSCLC tissue }(n \\
=55) \text { and normal lung tissue }(n=17)\end{array}$ & Real-time PCR and IHC & Increased & [17] \\
\hline & $\begin{array}{l}\text { Primary NSCLC and adjacent matched normal } \\
\text { tissue }(n=46)\end{array}$ & Western blotting & Decreased (26\%) & {$[42]$} \\
\hline & Primary NSCLS tissue $(n=36)$ & PCR & Increased (16\%) & [18] \\
\hline $\begin{array}{l}\text { Ovarian } \\
\text { cancer }\end{array}$ & $\begin{array}{l}\text { Ovarian cancer }(n=4) \text { and ovarian tissue from } \\
\text { endometriosis }(n=1)\end{array}$ & 2D-DIGE and LC-MS/MS & Increased & [19] \\
\hline \multirow[t]{3}{*}{$\begin{array}{l}\text { Pancreatic } \\
\text { cancer }\end{array}$} & $\begin{array}{l}\text { Pancreatic cancer and adjacent normal tissue ( } n \\
=31 \text { ) }\end{array}$ & $\mathrm{IHC}$ & Increased & {$[20]$} \\
\hline & $\begin{array}{l}\text { Pancreatic cancer }(n=100) \text { and adjacent normal } \\
\text { tissue }(n=80)\end{array}$ & $\mathrm{IHC}$ & Increased (48\%) & [21] \\
\hline & $\begin{array}{l}\text { Primary pancreatic and adjacent normal tissue ( } n \\
=3 \text { ) }\end{array}$ & Western blot & Increased & [22] \\
\hline $\begin{array}{l}\text { Prostate } \\
\text { cancer }\end{array}$ & Exosomes from prostate cancer cell lines & $\begin{array}{l}\text { Western blot and mass } \\
\text { spectrometry }\end{array}$ & Decreased & [43] \\
\hline
\end{tabular}

2D-DIGE: two-dimensional differential in gel electrophoresis; HCC: hepatocellular carcinoma; HPLC: high performance liquid chromatography; IHC: immunohistochemistry; LC-MS/MS: liquid chromatography tandem mass spectrometry; MALDI-TOF: matrix assisted laser desorption/ionization time of flight; NSCLC: non-small cell lung cancer; PCR: polymerase chain reaction; AML: acute myeloid leukaemia; TCGA: the cancer genome atlas; GEO: gene expression omnibus

and exhibit an increased expression of proteins involved in both oxidative stress- and sirtuin-induced autophagy ${ }^{\left[{ }^{[62]}\right.}$. Taken together, these studies demonstrate that $\alpha$-enolase is an important regulator of tumour cell metabolism, proliferation and survival, which by definition make it a perfect target for anticancer therapy. 


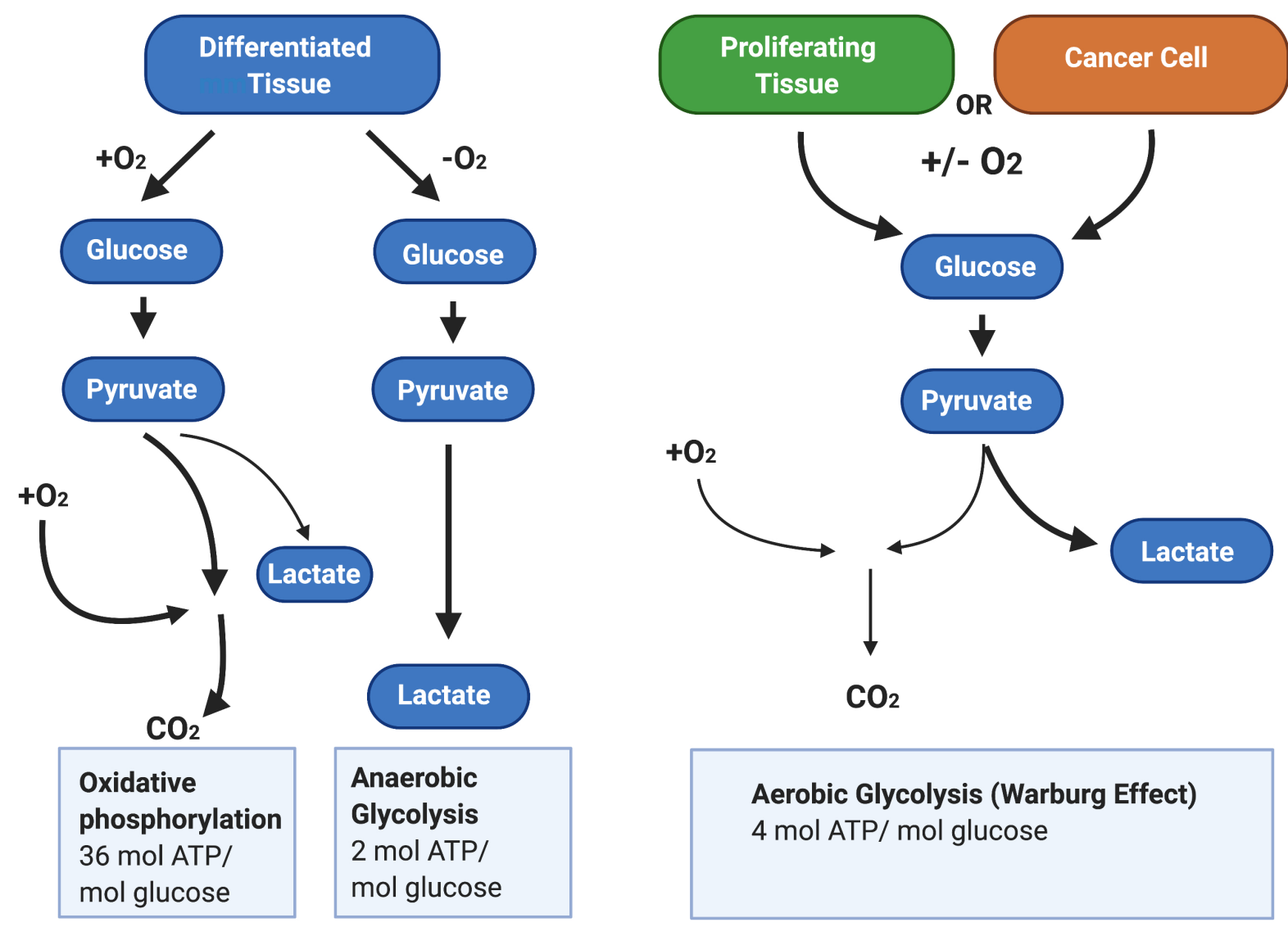

Figure 2. The Warburg Effect in cancer cells. In the presence of oxygen, differentiated tissues first metabolise glucose to pyruvate via glycolysis and then oxidise the majority of the pyruvate to carbon dioxide via oxidative phosphorylation. In situations where oxygen is low, cells redirect pyruvate generated by glycolysis away from oxidative phosphorylation by generating lactate via anaerobic glycolysis. By contrast, cancer cells convert most glucose to pyruvate regardless of whether oxygen is present. This allows cancer cells to meet the increased cellular energy demands

\section{ALPHA-ENOLASE IS A SURFACE PLASMINOGEN-BINDING RECEPTOR}

In addition to a role in cell proliferation and survival, $\alpha$-enolase located on the plasma membrane acts as a plasminogen-binding receptor ${ }^{[55]}$ [Figure 3]. Plasminogen is a zymogen, which is converted to plasmin in the presence of the activators tissue plasminogen activator or urokinase-type plasminogen activator $(\mathrm{uPA})^{[65]}$. This cell surface interaction concentrates protease activity in the tissue surrounding the cell, protecting plasmin from inactivation by circulating $\alpha 2$-antiplasmin ${ }^{[6]}$. Plasmin activates collagenases and degrades fibrin and other matrix proteins, resulting in cell migration and invasion into tissue, ultimately underpinning cancer metastasis and relapse.

\section{Role in invasion and migration}

Overexpression of $\alpha$-enolase has been shown to increase the migration and invasion of hepatocellular carcinoma, colorectal and gastric cancer cells in $v^{i t r}{ }^{[11,58,60,61,67]}$ and to enhance colorectal cancer metastasis in $v i v{ }^{[11]}$, demonstrating that it is an important driver of metastasis in multiple cancer types [Table 3]. Conversely, knockdown or pharmacological inhibition of $\alpha$-enolase decreased the migration and invasion of glioma, colorectal, pancreatic and endometrial carcinoma in vitro ${ }^{[6,12,63,68,69]}$, and decreased tumourigenesis and metastasis of endometrial carcinoma in vivo ${ }^{[12]}$. Furthermore, binding of recombinant $\alpha$-enolase to the surface of prostate cancer cells was shown to promote cell migration via its plasminogen receptor activity ${ }^{[70]}$. By contrast, anti- $\alpha$-enolase monoclonal antibodies inhibited plasminogen-dependent invasion of human pancreatic cancer cells in vitro and metastasis formation in vivo ${ }^{[71]}$ and also lung cancer cell invasion in vitro and growth in vivo ${ }^{[72]}$ [Table 3]. 
Table 2. Alpha-enolase controls cancer cell proliferation and survival

\begin{tabular}{|c|c|c|c|}
\hline Cancer & Experimental model & Effect of modulation of ENO1 expression & Ref. \\
\hline Bladder cancer & $\begin{array}{l}\text { Overexpression and knockdown in } \\
\text { T253 and } 5637 \text { cells }\end{array}$ & $\begin{array}{l}\text { Knockdown decreased cell proliferation and colony formation. } \\
\text { Overexpression increased cell proliferation and colony } \\
\text { formation }\end{array}$ & {$[59]$} \\
\hline Breast cancer & $\begin{array}{l}\text { Downregulation in MDA-MB-231 } \\
\text { cells }\end{array}$ & $\begin{array}{l}\text { Downregulation decreased cell proliferation and survival in } \\
\text { vitro and reduced tumour growth in vivo }\end{array}$ & [62] \\
\hline Colorectal cancer & $\begin{array}{l}\text { Overexpression and knockdown in } \\
\text { HCT116 cells }\end{array}$ & $\begin{array}{l}\text { Overexpression promoted cell proliferation and tumour growth } \\
\text { in vivo; Decreased expression decreased cell proliferation and } \\
\text { tumour growth in vivo }\end{array}$ & {$[11]$} \\
\hline Endometrial carcinoma & Knockdown in HEC-1B and Ishikawa & $\begin{array}{l}\text { Decreased expression reduced cell proliferation in vitro and } \\
\text { tumourigenesis in vivo }\end{array}$ & [12] \\
\hline \multirow[t]{4}{*}{ Gastric cancer } & $\begin{array}{l}\text { Knockdown in MGC-803 and MKN45 } \\
\text { cells }\end{array}$ & $\begin{array}{l}\text { Knockdown led to cell cycle arrest at the } \mathrm{G}_{1} \text { phase and } \\
\text { promoted apoptosis, and repressed the rate of cell } \\
\text { proliferation and colony formation }\end{array}$ & {$[13]$} \\
\hline & Knockdown in MKN45 cells & $\begin{array}{l}\text { Knockdown decreased cell proliferation, induced apoptosis } \\
\text { and increased sensitivity to chemotherapeutics }\end{array}$ & [64] \\
\hline & $\begin{array}{l}\text { Knockdown in AGS cells and } \\
\text { overexpression in SGC7901 cells }\end{array}$ & $\begin{array}{l}\text { Knockdown decreased proliferation and colony formation, } \\
\text { whereas overexpression increased cell proliferation and colony } \\
\text { formation }\end{array}$ & {$[60]$} \\
\hline & Overexpression in AGS cells & $\begin{array}{l}\text { Overexpression increased cell proliferation and colony } \\
\text { formation }\end{array}$ & {$[61]$} \\
\hline Glioma & Knockdown in U-87MG cells & $\begin{array}{l}\text { Knockdown suppressed cell proliferation and colony formation } \\
\text { in vitro and tumour growth in vivo }\end{array}$ & {$[6]$} \\
\hline $\mathrm{HCC}$ & Knockdown in HCC cells & Knockdown inhibited cell growth & [58] \\
\hline Lung cancer & Knockdown in $\mathrm{NCl}-\mathrm{H} 441$ cells & Knockdown decreased cell proliferation and survival & {$[62]$} \\
\hline Pancreatic cancer & Knockdown in CFPAC-1 cells & $\begin{array}{l}\text { Downregulation decreased cell proliferation and survival in } \\
\text { vitro and reduced tumour growth in vivo }\end{array}$ & [62] \\
\hline Retinoblastoma & $\begin{array}{l}\text { Knockdown in Y79 cells and } \\
\text { overexpression in Meri-RB1 cells }\end{array}$ & $\begin{array}{l}\text { Knockdown led to cell cycle arrest at the } \mathrm{G}_{1} \text { phase, decreased } \\
\text { cell proliferation and increased apoptosis. Overexpression } \\
\text { increased cell proliferation. }\end{array}$ & [57] \\
\hline
\end{tabular}

HCC: hepatocellular carcinoma

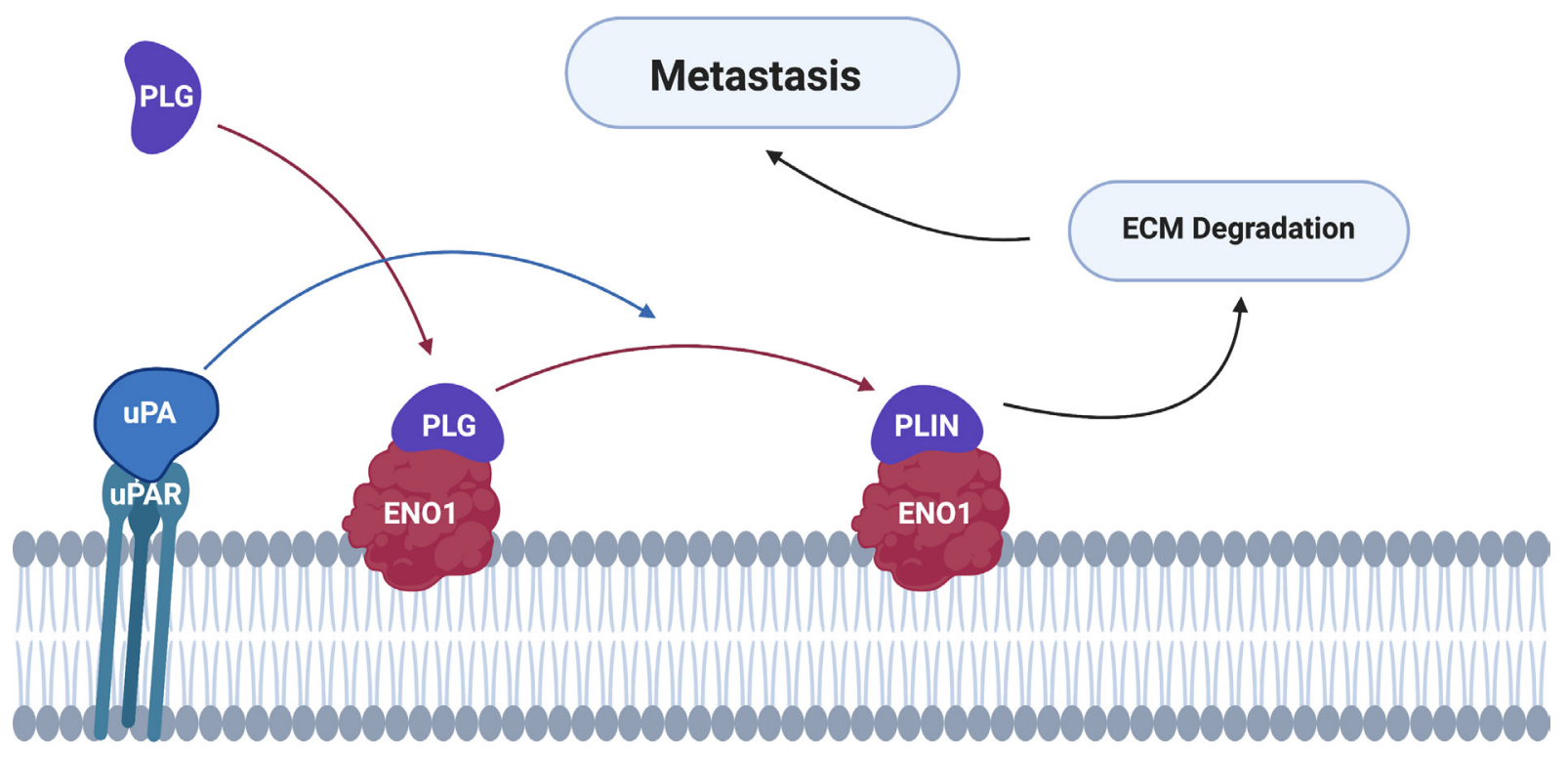

Figure 3. Alpha-enolase acts as a surface plasminogen-binding receptor to mediate cancer cell invasion and metastasis formation. PLG binds to its receptors and is subsequently converted to PLIN by plasminogen activators (e.g., uPA). Cell surface-associated plasmin facilitates degradation of the ECM, allowing tumour cells to invade and metastasise into other tissues. PLG: plasminogen; PLIN: plasmin; ECM: extracellular matrix; uPA: urokinase-type plasminogen activator 
Table 3. Alpha-enolase is a potential regulator of metastasis

\begin{tabular}{|c|c|c|c|}
\hline Cancer & Experimental model & Effect of modulation of ENO1 expression & Ref. \\
\hline \multirow[t]{2}{*}{ Colorectal cancer } & $\begin{array}{l}\text { Overexpression and knockdown in HCT116 } \\
\text { cells }\end{array}$ & $\begin{array}{l}\text { Overexpression increased migration and invasion both in vitro } \\
\text { and in vivo; decreased expression decreased migration and } \\
\text { invasion both in vitro and in vivo }\end{array}$ & {$[11]$} \\
\hline & $\begin{array}{l}\text { Treatment of HCT116 cells with CS5931 } \\
\text { (peptide inhibitor) }\end{array}$ & Treatment with CS5931 decreased cell migration and invasion & [69] \\
\hline $\begin{array}{l}\text { Endometrial } \\
\text { carcinoma }\end{array}$ & Knockdown in HEC-1B and Ishikawa & $\begin{array}{l}\text { Decreased expression reduced migration and invasion in vitro } \\
\text { and metastasis in vivo }\end{array}$ & {$[12]$} \\
\hline \multirow[t]{2}{*}{ Gastric cancer } & $\begin{array}{l}\text { Knockdown in AGS cells and overexpression } \\
\text { in SGC7901 cells }\end{array}$ & $\begin{array}{l}\text { Knockdown decreased migration, and overexpression increased } \\
\text { migration }\end{array}$ & {$[60]$} \\
\hline & Overexpression in AGS cells & Overexpression increased migration & [61] \\
\hline \multirow[t]{2}{*}{ Glioma } & Knockdown in U251-MG-WBP2 cells & Knockdown decreased migration & [63] \\
\hline & Knockdown in U-87MG cells & Knockdown suppressed migration and invasion & {$[6]$} \\
\hline \multirow[t]{2}{*}{$\mathrm{HCC}$} & Knockdown in HCC cells & Knockdown inhibited migration & [58] \\
\hline & Overexpression in HepG-2 cells & Increased migration and invasion & [67] \\
\hline Lung cancer & $\begin{array}{l}\text { Anti-human ENO1 antibody and knockdown } \\
\text { in A549 cells }\end{array}$ & $\begin{array}{l}\text { Downregulation and adoptive transfer of anti-human ENO1 } \\
\text { antibody decreased invasion in vitro and in vivo }\end{array}$ & [72] \\
\hline \multirow[t]{2}{*}{ Pancreatic cancer } & Knockdown in CFPAC-1 cells & $\begin{array}{l}\text { Knockdown decreased migration and invasion, and reduced } \\
\text { adhesion to fibronection and collagen and increased adhesion to } \\
\text { vitronectin }\end{array}$ & [68] \\
\hline & Anti-human ENO1 antibody & Decreased invasion in vitro and metastasis in vivo & {$[71]$} \\
\hline
\end{tabular}

HCC: hepatocellular carcinoma

\section{ALPHA-ENOLASE IS A TUMOUR-ASSOCIATED ANTIGEN}

Externalisation of $\alpha$-enolase by cancer cells exposes it to the immune system as a tumour-associated antigen that has been found to induce autoantibody production in cancer patients, including those with acute and chronic leukaemias, melanoma, and lung, breast, gastric and pancreatic cancers ${ }^{[22,45,73-79]}$. In pancreatic cancer, T cells activated by $\alpha$-enolase-pulsed dendritic cells lysed pancreatic cancer cells, but not normal human keratinocytes in vitro and inhibited CF-PAC-1 tumour growth in vivo ${ }^{[22]}$. In oral squamous cell carcinoma, an HLA-DR8-restricted human $\alpha$-enolase peptide was recognised by $\mathrm{CD}_{4}{ }^{+} \mathrm{T}$ cells and produced a cytotoxic response against OSC-20 cells ${ }^{[80]}$. Additionally, vaccination with $E N O 1$ in $\mathrm{Kras}^{\mathrm{G} 12 \mathrm{D} /}$ Cre and $\mathrm{Kras}^{\mathrm{G} 12 \mathrm{D}} / \operatorname{Trp} 53^{\mathrm{R} 172 \mathrm{H}}$ mice prior to development of pancreatic carcinoma delayed tumour growth and increased survival ${ }^{[81]}$. Taken together, these studies suggest that immune responses directed against $\alpha$-enolase may be immunostimulatory and ultimately beneficial to patients.

\section{ALPHA-ENOLASE IS A PROGNOSTIC FACTOR FOR MULTIPLE CANCER TYPES}

In addition to being overexpressed in many cancers, $\alpha$-enolase has been identified as a putative prognostic biomarker in a range of tumour types [Table 4]. Whilst ENO1 expression was not associated with tumour stage in colorectal cancers, it was significantly correlated with tumour size and presence of distant metastases ${ }^{[11]}$. Alpha-enolase expression was positively correlated with lymph node status in endometrial and gastric cancer patients ${ }^{[12,13,60]}$, and increased $\alpha$-enolase expression in endometrial, gastric, lung, lymphoma and hepatocellular cancer patients was associated with worse overall survival ${ }^{[8,12,13,16,73,82]}$. Furthermore, increased $\alpha$-enolase expression was correlated with worse distant metastasis-free survival in breast cancer patients ${ }^{[9]}$, worse disease-free survival in hepatocellular carcinoma and chordoma ${ }^{[16,83]}$ and worse progression-free survival in lung cancer patients ${ }^{[73]}$. By contrast, downregulation of $\alpha$-enolase is a predictor of poor prognosis in clear cell renal cell carcinoma $(\mathrm{ccRCC})^{[84]}$, demonstrating that $\alpha$-enolase may control different cellular functions in ccRCC when compared to other cancers.

Autoantibodies generated against $\alpha$-enolase in its capacity as a tumour-associated antigen represent an additional type of prognostic biomarker that may be assayed in serum. The presence of autoantibodies against $\alpha$-enolase correlated with longer disease-free survival and overall survival in pancreatic and lung cancer patients $^{[45,85-87]}$ [Table 4]. Furthermore, compared with healthy individuals, $\alpha$-enolase antibodies 
Table 4. $\alpha$-Enolase is a prognostic biomarker for a range of cancer types

\begin{tabular}{|c|c|c|c|}
\hline Cancer & Sample type & Patient outcome & Ref. \\
\hline Breast cancer & $\begin{array}{l}\text { Kaplan-Meier Plotter database }(n=5143 \text { breast } \\
\text { cancer patients) }\end{array}$ & $\begin{array}{l}\text { Increased mRNA expression correlated with worse } \\
\text { DMFS }\end{array}$ & {$[9]$} \\
\hline Chordoma & Cervical or sacral spine chordomas $(n=39)$ & $\begin{array}{l}\text { Increased protein expression was associated with } \\
\text { worse disease-free survival }\end{array}$ & {$[83]$} \\
\hline CLL & Sera from CLL patients $(n=86)$ & $\begin{array}{l}\text { Presence of anti- } \alpha \text {-enolase antibodies was predictive } \\
\text { of a shorter time to first treatment }\end{array}$ & {$[90]$} \\
\hline Colorectal cancer & Colorectal tumour tissues $(n=41)$ & $\begin{array}{l}\text { Protein expression correlated with tumour size and } \\
\text { distant metastasis }\end{array}$ & {$[11]$} \\
\hline Endometrial cancer & Endometrial cancer tissue $(n=100)$ & $\begin{array}{l}\text { Protein expression correlated with lymph node status } \\
\text { and depth of myometrial invasion; patients with high } \\
\text { expression had worse OS }\end{array}$ & {$[12]$} \\
\hline \multirow[t]{2}{*}{ Gastric cancer } & Gastric cancer tissue $(n=76)$ & $\begin{array}{l}\text { Protein expression correlated with lymph node } \\
\text { metastasis and TNM stage }\end{array}$ & {$[60]$} \\
\hline & $\begin{array}{l}\text { TCGA dataset ( } n=410 \text { gastric cancer patients); } \\
\text { Gastric cancer tissue }(n=94)\end{array}$ & $\begin{array}{l}\text { Protein expression correlated with high TNM stage } \\
\text { and metastasis; Increased mRNA was associated } \\
\text { with poor OS }\end{array}$ & {$[13]$} \\
\hline \multirow[t]{2}{*}{$\mathrm{HCC}$} & $\begin{array}{l}\text { TCGA dataset ( } n=374 \text { HCC tissues); meta- } \\
\text { analysis of } 12 \text { cohorts in GEO database }\end{array}$ & $\begin{array}{l}\text { Increased mRNA was associated with poor OS and } \\
\text { disease-free survival; Protein expression correlated } \\
\text { with high TNM stage and was negatively correlated } \\
\text { with OS }\end{array}$ & {$[16]$} \\
\hline & Sera from HCC patients $(n=61)$ & $\begin{array}{l}\text { Anti- } \alpha \text {-enolase antibodies were lower in patients } \\
\text { without microvascular invasion compared to those } \\
\text { with microvascular invasion }\end{array}$ & {$[91]$} \\
\hline \multirow[t]{4}{*}{ Lung cancer } & $\begin{array}{l}\text { Kaplan-Meier Plotter database }(n=348 \text { lung } \\
\text { cancer patients); Lung adenocarcinoma tissue ( } n \\
=37 \text { ) }\end{array}$ & $\begin{array}{l}\text { Increased mRNA and protein was associated with } \\
\text { poor OS; Increased expression was associated with } \\
\text { bone metastasis incidence }\end{array}$ & {$[82]$} \\
\hline & Malignant pleural effusion samples $(n=54)$ & High protein was associated with poor OS and PFS & {$[73]$} \\
\hline & $\begin{array}{l}\text { Plasma from non-small lung carcinoma patients } \\
(n=85)\end{array}$ & $\begin{array}{l}\text { Patients with a higher increase in anti- } \alpha \text {-enolase had } \\
\text { a lower hazard ratio and better PFS }\end{array}$ & {$[85]$} \\
\hline & $\begin{array}{l}\text { Sera from patients with lung cancer }(n=72) \text {, } \\
\text { benign lung diseases }(n=69) \text {, and healthy } \\
\text { individuals }(n=70)\end{array}$ & $\begin{array}{l}\text { Autoantibodies were higher in lung cancer sera } \\
\text { compared with sera from normal and benign lung } \\
\text { disease patients; Autoantibodies were higher in stage } \\
\text { I/II than in stage III/IV }\end{array}$ & {$[89]$} \\
\hline Lymphoma & $\begin{array}{l}\text { Peripheral T-cell lymphoma not otherwise } \\
\text { classified tissue }(n=87)\end{array}$ & Increased protein correlated with worse OS & {$[8]$} \\
\hline \multirow[t]{2}{*}{ Pancreatic cancer } & $\begin{array}{l}\text { Sera from pancreatic ductal adenocarcinoma } \\
\text { patients }(n=120)\end{array}$ & $\begin{array}{l}\text { Presence of auto-antibodies correlated with a better } \\
\text { clinical outcome }\end{array}$ & [86] \\
\hline & $\begin{array}{l}\text { Sera and PBMCs from pancreatic ductal } \\
\text { adenocarcinoma patients }(n=15)\end{array}$ & $\begin{array}{l}\text { Patients with }>20 \% \text { peripheral } \alpha \text {-enolase-specific } \\
\text { T cells or anti- } \alpha \text {-enolase antibodies showed a better } \\
\text { OS }\end{array}$ & {$[87]$} \\
\hline $\operatorname{ccRCC}$ & $\begin{array}{l}\text { Primary ccRCC tissue }(n=360) \text { and TCGA } \\
\text { dataset }(n=428)\end{array}$ & $\begin{array}{l}\text { Negative correlation between protein expression, } \\
\text { tumour stage and grade. Patients with higher mRNA } \\
\text { had lower hazard ratio of recurrence and longer OS }\end{array}$ & {$[84]$} \\
\hline
\end{tabular}

ccRCC: clear cell renal cell carcinoma; CLL: chronic lymphoblastic leukaemia; DMFS: distant metastasis-free survival; GEO: gene expression omnibus; HCC: hepatocellular carcinoma; OS: overall survival; PBMC: peripheral blood mononuclear cell; PFS: progression-free survival; TCGA: the cancer genome atlas; TNM: tumour node metastasis

are decreased in stage IV lung and breast cancers ${ }^{[88]}$, and are lower in stage III/IV than in stage I/II lung cancer patients $^{[89]}$. By contrast, the presence of anti- $\alpha$-enolase antibodies in sera from chronic lymphocytic leukaemia (CLL) patients is predictive of a shorter time to first treatment ${ }^{[90]}$, indicating that the presence of $\alpha$-enolase antibodies are indicative of a disrupted immune system in CLL. Taken together, these studies suggest that autoantibodies against $\alpha$-enolase are a good prognostic factor in pancreatic, lung and breast cancers, and provide further evidence that targeting $\alpha$-enolase may be beneficial in solid tumours.

\section{ENOLASE INHIBITORS ARE POTENTIAL ANTICANCER AGENTS}

Due to its important cancer-related roles, enolase is one of several glycolytic enzymes being examined as a potential anticancer therapeutic target. Polyamine sulphonamide analogues have proven particularly effective at inhibiting $\alpha$-enolase activity. Two such compounds have been further developed and shown to 
be cytotoxic to KG-1 (AML) cells and to the AML leukaemic stem cell fraction, with minimal effects on normal healthy stem cells ${ }^{[92]}$. This report highlights that $\alpha$-enolase is an actionable therapeutic target that may be useful in the treatment of cancer, particularly AML.

\section{CONCLUSION}

Alpha-enolase plays a supportive role in cancer progression and has been implicated in three of the hallmarks of cancer: cellular energetics and metabolism; cell proliferation; and invasion and migration. In cancer cells, $\alpha$-enolase is overexpressed and localised on the surface, where it acts as a key promotor of metastasis, driving invasion through plasminogen activation and extracellular matrix degradation. In several cancer types, patients develop an immune response against $\alpha$-enolase, and anti- $\alpha$-enolase antibodies can be detected in their sera. Increased expression of $\alpha$-enolase mRNA, proteins or autoantibodies are associated with decreased metastasis-free survival in several cancer types, including non-small cell lung, pancreatic, breast and colorectal cancers. Future examination of the expression and function of $\alpha$-enolase in cancers may ultimately result in $\alpha$-enolase becoming a therapeutic target and prognostic biomarker for a range of cancer types.

\section{DECLARATIONS}

\section{Authors' contributions}

Contributed to the drafting and editing of this manuscript: Schofield L, Lincz LF, Skelding KA

\section{Availability of data and materials}

Not applicable.

\section{Financial support and sponsorship}

This work was funded by grants from the Calvary Mater Newcastle and Hunter Medical Research Institute.

\section{Conflicts of interest}

All authors declared that there are no conflicts of interest.

\section{Ethical approval and consent to participate}

Not applicable.

\section{Consent for publication}

Not applicable.

\section{Copyright}

(c) The Author(s) 2020.

\section{REFERENCES}

1. Liberti MV, Locasale JW. The warburg effect: how does it benefit cancer cells? Trends Biochem Sci 2016;41:211-8.

2. Hanahan D, Weinberg RA. Hallmarks of cancer: the next generation. Cell 2011;144:646-74.

3. Kim JW, Dang CV. Multifaceted roles of glycolytic enzymes. Trends Biochem Sci 2005;30:142-50.

4. Handschuh L, Kazmierczak M, Milewski MC, Goralski M, Luczak M, et al. Gene expression profiling of acute myeloid leukemia samples from adult patients with AML-M1 and -M2 through boutique microarrays, real-time PCR and droplet digital PCR. Int J Oncol 2018;52:656-78.

5. Beckner ME, Fellows-Mayle W, Zhang Z, Agostino NR, Kant JA, et al. Identification of ATP citrate lyase as a positive regulator of glycolytic function in glioblastomas. Int J Cancer 2010;126:2282-95.

6. Song Y, Luo Q, Long H, Hu Z, Que T, et al. Alpha-enolase as a potential cancer prognostic marker promotes cell growth, migration, and invasion in glioma. Mol Cancer 2014;13:65.

7. Cecconi D, Carbonare LD, Mori A, Cheri S, Deiana M, et al. An integrated approach identifies new oncotargets in melanoma. Oncotarget 
2018;9:11489-502.

8. Ludvigsen M, Bjerregard Pedersen M, Lystlund Lauridsen K, Svenstrup Poulsen T, Hamilton-Dutoit SJ, et al. Proteomic profiling identifies outcome-predictive markers in patients with peripheral T-cell lymphoma, not otherwise specified. Blood Adv 2018;2:2533-42.

9. Cancemi P, Buttacavoli M, Roz E, Feo S. Expression of alpha-enolase (ENO1), myc promoter-binding protein-1 (MBP-1) and matrix metalloproteinases (MMP-2 and MMP-9) reflect the nature and aggressiveness of breast tumors. Int J Mol Sci 2019;20.

10. Tu SH, Chang CC, Chen CS, Tam KW, Wang YJ, et al. Increased expression of enolase alpha in human breast cancer confers tamoxifen resistance in human breast cancer cells. Breast Cancer Res Treat 2010;121:539-53.

11. Zhan P, Zhao S, Yan H, Yin C, Xiao Y, et al. alpha-enolase promotes tumorigenesis and metastasis via regulating AMPK/mTOR pathway in colorectal cancer. Mol Carcinog 2017;56:1427-37.

12. Zhao M, Fang W, Wang Y, Guo S, Shu L, et al. Enolase-1 is a therapeutic target in endometrial carcinoma. Oncotarget 2015;6:15610-27.

13. Qiao H, Wang Y, Zhu B, Jiang L, Yuan W, et al. Enolase1 overexpression regulates the growth of gastric cancer cells and predicts poor survival. J Cell Biochem 2019;120:18714-23.

14. Zhou X, Yao K, Zhang L, Zhang Y, Han Y, et al. Identification of differentiation-related proteins in gastric adenocarcinoma tissues by proteomics. Technol Cancer Res Treat 2016;15:697-706.

15. Tsai ST, Chien IH, Shen WH, Kuo YZ, Jin YT, et al. ENO1, a potential prognostic head and neck cancer marker, promotes transformation partly via chemokine CCL20 induction. Eur J Cancer 2010;46:1712-23.

16. Zhu W, Li H, Yu Y, Chen J, Chen X, et al. Enolase-1 serves as a biomarker of diagnosis and prognosis in hepatocellular carcinoma patients. Cancer Manag Res 2018;10:5735-45.

17. Fu QF, Liu Y, Fan Y, Hua SN, Qu HY, et al. Alpha-enolase promotes cell glycolysis, growth, migration, and invasion in non-small cell lung cancer through FAK-mediated PI3K/AKT pathway. J Hematol Oncol 2015;8:22.

18. Racz A, Brass N, Hofer M, Sybrecht GW, Remberger K, et al. Gene amplification at chromosome 1pter-p33 including the genes PAX7 and ENO1 in squamous cell lung carcinoma. Int J Oncol 2000;17:67-73.

19. Cruz IN, Coley HM, Kramer HB, Madhuri TK, Safuwan NA, et al. Proteomics analysis of ovarian cancer cell lines and tissues reveals drug resistance-associated proteins. Cancer Genomics Proteomics 2017;14:35-51.

20. Yin H, Wang L, Liu HL. ENO1 overexpression in pancreatic cancer patients and its clinical and diagnostic significance. Gastroenterol Res Pract 2018;2018:3842198.

21. Sun L, Guo C, Cao J, Burnett J, Yang Z, et al. Over-expression of alpha-enolase as a prognostic biomarker in patients with pancreatic cancer. Int J Med Sci 2017;14:655-61.

22. Cappello P, Tomaino B, Chiarle R, Ceruti P, Novarino A, et al. An integrated humoral and cellular response is elicited in pancreatic cancer by alpha-enolase, a novel pancreatic ductal adenocarcinoma-associated antigen. Int J Cancer 2009;125:639-48.

23. Marangos PJ, Parma AM, Goodwin FK. Functional properties of neuronal and glial isoenzymes of brain enolase. J Neurochem 1978;31:727-32.

24. Kang HJ, Jung SK, Kim SJ, Chung SJ. Structure of human alpha-enolase (hENO1), a multifunctional glycolytic enzyme. Acta Crystallogr D Biol Crystallogr 2008;64:651-7.

25. Brewer JM. Yeast enolase: mechanism of activation by metal ions. CRC Crit Rev Biochem 1981;11:209-54.

26. Petrak J, Ivanek R, Toman O, Cmejla R, Cmejlova J, et al. Deja vu in proteomics. A hit parade of repeatedly identified differentially expressed proteins. Proteomics 2008;8:1744-9.

27. Castegna A, Aksenov M, Thongboonkerd V, Klein JB, Pierce WM, et al. Proteomic identification of oxidatively modified proteins in Alzheimer's disease brain. Part II: dihydropyrimidinase-related protein 2, alpha-enolase and heat shock cognate 71 . J Neurochem 2002;82:1524-32.

28. Owen JB, Di Domenico F, Sultana R, Perluigi M, Cini C, et al. Proteomics-determined differences in the concanavalin-A-fractionated proteome of hippocampus and inferior parietal lobule in subjects with Alzheimer's disease and mild cognitive impairment: implications for progression of AD. J Proteome Res 2009;8:471-82.

29. Butterfield DA, Lange ML. Multifunctional roles of enolase in Alzheimer's disease brain: beyond altered glucose metabolism. J Neurochem 2009;111:915-33.

30. Kinloch A, Tatzer V, Wait R, Peston D, Lundberg K, et al. Identification of citrullinated alpha-enolase as a candidate autoantigen in rheumatoid arthritis. Arthritis Res Ther 2005;7:R1421-9.

31. Montes A, Dieguez-Gonzalez R, Perez-Pampin E, Calaza M, Mera-Varela A, et al. Particular association of clinical and genetic features with autoimmunity to citrullinated alpha-enolase in rheumatoid arthritis. Arthritis Rheum 2011;63:654-61.

32. Mehra S, Walker J, Patterson K, Fritzler MJ. Autoantibodies in systemic sclerosis. Autoimmun Rev 2013;12:340-54.

33. Terrier B, Tamby MC, Camoin L, Guilpain P, Berezne A, et al. Antifibroblast antibodies from systemic sclerosis patients bind to \{alpha\}enolase and are associated with interstitial lung disease. Ann Rheum Dis 2010;69:428-33.

34. Bergmann S, Schoenen H, Hammerschmidt S. The interaction between bacterial enolase and plasminogen promotes adherence of Streptococcus pneumoniae to epithelial and endothelial cells. Int J Med Microbiol 2013;303:452-62.

35. Funk J, Schaarschmidt B, Slesiona S, Hallstrom T, Horn U, et al. The glycolytic enzyme enolase represents a plasminogen-binding protein on the surface of a wide variety of medically important fungal species. Int J Med Microbiol 2016;306:59-68.

36. Li M, Li J, Wang J, Li Y, Yang P. Serum level of anti-alpha-enolase antibody in untreated systemic lupus erythematosus patients correlates with 24-hour urine protein and D-dimer. Lupus 2018;27:139-42.

37. Peng B, Huang X, Nakayasu ES, Petersen JR, Qiu S, et al. Using immunoproteomics to identify alpha-enolase as an autoantigen in liver fibrosis. J Proteome Res 2013;12:1789-96. 
38. Zhang B, Wang Z, Deng B, Wu X, Liu J, et al. Identification of Enolase 1 and Thrombospondin-1 as serum biomarkers in HBV hepatic fibrosis by proteomics. Proteome Sci 2013;11:30.

39. Feo S, Arcuri D, Piddini E, Passantino R, Giallongo A. ENO1 gene product binds to the c-myc promoter and acts as a transcriptional repressor: relationship with Myc promoter-binding protein 1 (MBP-1). FEBS Lett 2000;473:47-52.

40. Bae SM, Min HJ, Ding GH, Kwak SY, Cho YL, et al. Protein expression profile using two-dimensional gel analysis in squamous cervical cancer patients. Cancer Res Treat 2006;38:99-107.

41. Katayama M, Nakano H, Ishiuchi A, Wu W, Oshima R, et al. Protein pattern difference in the colon cancer cell lines examined by twodimensional differential in-gel electrophoresis and mass spectrometry. Surg Today 2006;36:1085-93.

42. Chang YS, Wu W, Walsh G, Hong WK, Mao L. Enolase-alpha is frequently down-regulated in non-small cell lung cancer and predicts aggressive biological behavior. Clin Cancer Res 2003;9:3641-4.

43. Duijvesz D, Burnum-Johnson KE, Gritsenko MA, Hoogland AM, Vredenbregt-van den Berg MS, et al. Proteomic profiling of exosomes leads to the identification of novel biomarkers for prostate cancer. PLoS One 2013;8:e82589.

44. Seweryn E, Pietkiewicz J, Bednarz-Misa IS, Ceremuga I, Saczko J, et al. Localization of enolase in the subfractions of a breast cancer cell line. Z Naturforsch C J Biosci 2009;64:754-8.

45. He P, Naka T, Serada S, Fujimoto M, Tanaka T, et al. Proteomics-based identification of alpha-enolase as a tumor antigen in non-small lung cancer. Cancer Sci 2007;98:1234-40.

46. Mears R, Craven RA, Hanrahan S, Totty N, Upton C, et al. Proteomic analysis of melanoma-derived exosomes by two-dimensional polyacrylamide gel electrophoresis and mass spectrometry. Proteomics 2004;4:4019-31.

47. Greening DW, Ji H, Chen M, Robinson BW, Dick IM, et al. Secreted primary human malignant mesothelioma exosome signature reflects oncogenic cargo. Sci Rep 2016;6:32643.

48. Pan D, Chen J, Feng C, Wu W, Wang Y, et al. Preferential localization of MUC1 glycoprotein in exosomes secreted by non-small cell lung carcinoma cells. Int J Mol Sci 2019;20.

49. Valcz G, Galamb O, Krenacs T, Spisak S, Kalmar A, et al. Exosomes in colorectal carcinoma formation: ALIX under the magnifying glass. Mod Pathol 2016;29:928-38.

50. Didiasova M, Schaefer L, Wygrecka M. When place matters: shuttling of enolase-1 across cellular compartments. Front Cell Dev Biol 2019;7:61.

51. Entelis N, Brandina I, Kamenski P, Krasheninnikov IA, Martin RP, et al. A glycolytic enzyme, enolase, is recruited as a cofactor of tRNA targeting toward mitochondria in Saccharomyces cerevisiae. Genes Dev 2006;20:1609-20.

52. Brandina I, Graham J, Lemaitre-Guillier C, Entelis N, Krasheninnikov I, et al. Enolase takes part in a macromolecular complex associated to mitochondria in yeast. Biochim Biophys Acta 2006;1757:1217-28.

53. Gao S, Li H, Cai Y, Ye JT, Liu ZP, et al. Mitochondrial binding of alpha-enolase stabilizes mitochondrial membrane: its role in doxorubicin-induced cardiomyocyte apoptosis. Arch Biochem Biophys 2014;542:46-55.

54. Aaronson RM, Graven KK, Tucci M, McDonald RJ, Farber HW. Non-neuronal enolase is an endothelial hypoxic stress protein. J Biol Chem 1995;270:27752-7.

55. Plow EF, Das R. Enolase-1 as a plasminogen receptor. Blood 2009;113:5371-2.

56. Lunt SY, Vander Heiden MG. Aerobic glycolysis: meeting the metabolic requirements of cell proliferation. Annu Rev Cell Dev Biol 2011;27:441-64.

57. Liu Y, Li H, Liu Y, Zhu Z. MiR-22-3p targeting alpha-enolase 1 regulates the proliferation of retinoblastoma cells. Biomed Pharmacother 2018;105:805-12.

58. Zhu X, Yu H, Li B, Quan J, Zeng Z, et al. Targetting an LncRNA P5848-ENO1 axis inhibits tumor growth in hepatocellular carcinoma. Biosci Rep 2019;39.

59. Ji M, Wang Z, Chen J, Gu L, Chen M, et al. Up-regulated ENO1 promotes the bladder cancer cell growth and proliferation via regulating beta-catenin. Biosci Rep 2019;39.

60. Sun L, Lu T, Tian K, Zhou D, Yuan J, et al. Alpha-enolase promotes gastric cancer cell proliferation and metastasis via regulating AKT signaling pathway. Eur J Pharmacol 2019;845:8-15.

61. Liu YQ, Huang ZG, Li GN, Du JL, Ou YP, et al. Effects of alpha-enolase (ENO1) over-expression on malignant biological behaviors of AGS cells. Int J Clin Exp Med 2015;8:231-9.

62. Capello M, Ferri-Borgogno S, Riganti C, Chattaragada MS, Principe M, et al. Targeting the Warburg effect in cancer cells through ENO1 knockdown rescues oxidative phosphorylation and induces growth arrest. Oncotarget 2016;7:5598-612.

63. Chen S, Zhang Y, Wang H, Zeng YY, Li Z, et al. WW domain-binding protein 2 acts as an oncogene by modulating the activity of the glycolytic enzyme ENO1 in glioma. Cell Death Dis 2018;9:347.

64. Qiao H, Wang YF, Yuan WZ, Zhu BD, Jiang L, et al. Silencing of ENO1 by shRNA inhibits the proliferation of gastric cancer cells. Technol Cancer Res Treat 2018;17:1533033818784411.

65. Syrovets T, Lunov O, Simmet T. Plasmin as a proinflammatory cell activator. J Leukoc Biol 2012;92:509-19.

66. Redlitz A, Fowler BJ, Plow EF, Miles LA. The role of an enolase-related molecule in plasminogen binding to cells. Eur J Biochem 1995;227:407-15.

67. Chen X, Xu H, Wu N, Liu X, Qiao G, et al. Interaction between granulin A and enolase 1 attenuates the migration and invasion of human hepatoma cells. Oncotarget 2017;8:30305-16.

68. Principe M, Borgoni S, Cascione M, Chattaragada MS, Ferri-Borgogno S, et al. Alpha-enolase (ENO1) controls alpha v/beta 3 integrin expression and regulates pancreatic cancer adhesion, invasion, and metastasis. J Hematol Oncol 2017;10:16. 
69. Su S, Xu H, Chen X, Qiao G, Farooqi AA, et al. CS5931, A novel marine polypeptide, inhibits migration and invasion of cancer cells via interacting with enolase 1. Recent Pat Anticancer Drug Discov 2018;13:360-7.

70. Yu L, Shi J, Cheng S, Zhu Y, Zhao X, et al. Estrogen promotes prostate cancer cell migration via paracrine release of ENO1 from stromal cells. Mol Endocrinol 2012;26:1521-30.

71. Principe M, Ceruti P, Shih NY, Chattaragada MS, Rolla S, et al. Targeting of surface alpha-enolase inhibits the invasiveness of pancreatic cancer cells. Oncotarget 2015;6:11098-113.

72. Hsiao KC, Shih NY, Fang HL, Huang TS, Kuo CC, et al. Surface alpha-enolase promotes extracellular matrix degradation and tumor metastasis and represents a new therapeutic target. PLoS One 2013;8:e69354.

73. Chang GC, Liu KJ, Hsieh CL, Hu TS, Charoenfuprasert S, et al. Identification of alpha-enolase as an autoantigen in lung cancer: its overexpression is associated with clinical outcomes. Clin Cancer Res 2006;12:5746-54.

74. Dai L, Qu Y, Li J, Wang X, Wang K, et al. Serological proteome analysis approach-based identification of ENO1 as a tumor-associated antigen and its autoantibody could enhance the sensitivity of CEA and CYFRA 21-1 in the detection of non-small cell lung cancer. Oncotarget 2017;8:36664-73.

75. Qin J, Wang S, Shi J, Ma Y, Wang K, et al. Using recursive partitioning approach to select tumor-associated antigens in immunodiagnosis of gastric adenocarcinoma. Cancer Sci 2019;110:1829-41.

76. Suzuki A, Iizuka A, Komiyama M, Takikawa M, Kume A, et al. Identification of melanoma antigens using a Serological Proteome Approach (SERPA). Cancer Genomics Proteomics 2010;7:17-23.

77. Cui JW, Li WH, Wang J, Li AL, Li HY, et al. Proteomics-based identification of human acute leukemia antigens that induce humoral immune response. Mol Cell Proteomics 2005;4:1718-24.

78. Zou L, Wu Y, Pei L, Zhong D, Gen M, et al. Identification of leukemia-associated antigens in chronic myeloid leukemia by proteomic analysis. Leuk Res 2005;29:1387-91.

79. Forgber M, Trefzer U, Sterry W, Walden P. Proteome serological determination of tumor-associated antigens in melanoma. PLoS One 2009; 4:e5199.

80. Kondo H, Sahara H, Miyazaki A, Nabeta Y, Hirohashi Y, et al. Natural antigenic peptides from squamous cell carcinoma recognized by autologous HLA-DR8-restricted CD4+ T cells. Jpn J Cancer Res 2002;93:917-24.

81. Cappello P, Rolla S, Chiarle R, Principe M, Cavallo F, et al. Vaccination with ENO1 DNA prolongs survival of genetically engineered mice with pancreatic cancer. Gastroenterology 2013;144:1098-106.

82. Yang M, Sun Y, Sun J, Wang Z, Zhou Y, et al. Differentially expressed and survival-related proteins of lung adenocarcinoma with bone metastasis. Cancer Med 2018;7:1081-92.

83. Zhou H, Chen CB, Lan J, Liu C, Liu XG, et al. Differential proteomic profiling of chordomas and analysis of prognostic factors. J Surg Oncol 2010;102:720-7.

84. White-Al Habeeb NM, Di Meo A, Scorilas A, Rotondo F, Masui O, et al. Alpha-enolase is a potential prognostic marker in clear cell renal cell carcinoma. Clin Exp Metastasis 2015;32:531-41.

85. Hsiao KC, Shih NY, Chu PY, Hung YM, Liao JY, et al. Anti-alpha-enolase is a prognostic marker in postoperative lung cancer patients. Oncotarget 2015;6:35073-86.

86. Tomaino B, Cappello P, Capello M, Fredolini C, Sperduti I, et al. Circulating autoantibodies to phosphorylated alpha-enolase are a hallmark of pancreatic cancer. J Proteome Res 2011;10:105-12.

87. Niccolai E, Cappello P, Taddei A, Ricci F, D’Elios MM, et al. Peripheral ENO1-specific T cells mirror the intratumoral immune response and their presence is a potential prognostic factor for pancreatic adenocarcinoma. Int J Oncol 2016;49:393-401.

88. Shih NY, Lai HL, Chang GC, Lin HC, Wu YC, et al. Anti-alpha-enolase autoantibodies are down-regulated in advanced cancer patients. Jpn J Clin Oncol 2010;40:663-9.

89. Zhang L, Wang H, Dong X. Diagnostic value of alpha-enolase expression and serum alpha-enolase autoantibody levels in lung cancer. J Bras Pneumol 2018;44:18-23.

90. Griggio V, Mandili G, Vitale C, Capello M, Macor P, et al. Humoral immune responses toward tumor-derived antigens in previously untreated patients with chronic lymphocytic leukemia. Oncotarget 2017;8:3274-88.

91. Yu YQ, Wang L, Jin Y, Zhou JL, Geng YH, et al. Identification of serologic biomarkers for predicting microvascular invasion in hepatocellular carcinoma. Oncotarget 2016;7:16362-71.

92. Fortunato S, Bononi G, Granchi C, Minutolo F. An update on patents covering agents that interfere with the cancer glycolytic cascade. ChemMedChem 2018;13:2251-65. 